\title{
Rituais indígenas na contemporaneidade brasileira: a (re)significação de práticas corporais do povo Bororo
}

\author{
Arthur José Medeiros de Almeida \\ Orientador: Prof. Dr. João Gabriel Lima Cruz Teixeira \\ Curso: Doutorado em Sociologia \\ Data da defesa: 12.04.2013
}

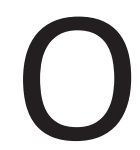

s indígenas da etnia Bororo, atualmente, habitam um território descontínuo formado por seis Terras Indígenas no estado de Mato Grosso, no centro-oeste do Brasil. Esse grupo étnico possui um valioso patrimônio cultural composto por um acervo de bens de natureza material e imaterial que remetem à totalidade da cultura Bororo. Os rituais expressam as normas, os conhecimentos e os valores culturais, bem como fabricam os corpos dos indígenas. Contudo, as práticas corporais que os compõem possuem sentidos e significados que são determinados socialmente. Compreendendo cultura como um processo dinâmico e que se configura como sistema simbólico, orientando as representações em diferentes sociedades, atenta-se, neste estudo, para as (re)significações das práticas corporais na contemporaneidade brasileira. O objetivo foi interpretar os sentidos e significados que as práticas corporais - futebol e danças - da etnia indígena Bororo assumem em diferentes contextos. Nesse sentido, o foco da investigação foi sobre a relação cultura-política, isto é, sobre os sentidos políticos que adquirem os bens culturais da etnia Bororo. A pesquisa, com abordagem qualitativa, foi desenvolvida por meio de levantamento bibliográfico e pesquisa de campo: (1) Jogos dos Povos Indígenas (2009 e 2011) e (2) aldeia Meruri (2011 e 2012). Nessas oportunidades foram utilizadas, como técnicas de pesquisa: a observação e a entrevista, configurando-se como uma pesquisa descritivo-interpretativa. A análise demonstra que o futebol constitui-se como a prática corporal mais vivenciada pelos Bororo no cotidiano da aldeia Meruri, sendo um importante meio de constituição da identidade étnica. As danças assumem diferentes sentidos, sendo eles: (1) construção do corpo e da política de identidade étnica; (2) formação de alianças políticas com os missionários salesianos; (3) exercício da autonomia política que vem sendo conquistada e; (4) formação de alianças políticas com associações indígenas e indigenistas. Compreende-se, portanto, que essas práticas corporais são meios de se promover uma intervenção estética e política na relação com os não índios, tendo como finalidade assegurar, exercer e reivindicar seus direitos. Espera-se que os 
conhecimentos produzidos neste estudo possam contribuir para o desenvolvimento das comunidades indígenas, fornecendo subsídios para a formulação de políticas públicas, bem como para a diminuição da intolerância aos direitos dos povos indígenas. O grupo indígena pesquisado, assim como outras comunidades tradicionais, almejam desenvolver-se, mantendo-se a diferenciação em relação a outros povos.

Palavras-chave: Cultura, Política, Rituais, Futebol, Danças. 